\title{
Changes in Characteristics of Kithul (Caryota urens) Flour Prepared by Different Modification Techniques
}

\author{
J. A. A. C. Wijesinghe, ${ }^{1}$ I. Wickramasinghe, ${ }^{1}$ and K. H. Saranandha ${ }^{2}$ \\ ${ }^{1}$ Department of Food Science and Technology, Faculty of Applied Sciences, University of Sri Jayewardenepura, \\ Gangodawila, Nugegoda, Sri Lanka \\ ${ }^{2}$ Food Research Unit, Gannoruwa Agriculture Research Center, P.O. Box 53, Peradeniya Kandy, Sri Lanka
}

Correspondence should be addressed to J. A. A. C. Wijesinghe; lucky.research@yahoo.com

Received 10 December 2015; Revised 22 February 2016; Accepted 22 March 2016

Academic Editor: Raquel P. Guiné

Copyright (C) 2016 J. A. A. C. Wijesinghe et al. This is an open access article distributed under the Creative Commons Attribution License, which permits unrestricted use, distribution, and reproduction in any medium, provided the original work is properly cited.

Flour has been an ample source of research and most abundant material for a number of food applications. The aim of this study is to introduce modified Kithul flour for certain industrial requirements. Several physical and chemical treatments were employed to modify Kithul (Caryota urens) flour. The effects of pregelatinization (PG-I and II), acid modification (AC), and dextrinization (DX) on their swelling power, solubility, granular morphology, viscosity, and X-ray diffraction (XRD) patterns were studied. At $75^{\circ} \mathrm{C}$, pregelatinized treated (PG-II) flour had a high solubility (5.31), while at $70^{\circ} \mathrm{C}$ pregelatinized treated (PG-I) flour had a low solubility (4.47) as compared to the solubility of native flour sample $(\mathrm{RW}=4.88)$. Same pattern has been followed by the swelling power while viscosity showed the highest value for PG-II (7296.51 Cp) and lowest value for DX treatment (873.40 Cp) as peak viscosities. There were no significant changes in granular size of all treatments compared with the native Kithul flour $(45.52 \mu \mathrm{m})$.

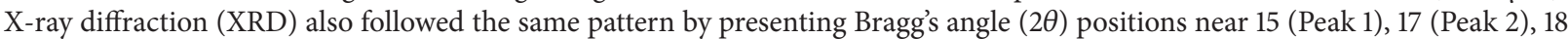
(Peak 3), and 23 (Peak 4) providing evidence for the presence of crystallites which belong to type A in all modified and native Kithul flour treatments.

\section{Introduction}

Starch is a very important raw material with a broad range of applications in a number of fields with a very high demand from the food industry $[1,2]$. It is a carbohydrate [3] biopolymer of glucose units constructed of amylose and amylopectin [4] as a renewable resource from green plants [5]. These two polymers (as amylose and amylopectin) are specific for starch properties [4] by forming amorphous and crystalline regions of the starch granule.

Based on the botanical source properties of starch it differs [6] and most of the native forms of starches are not suitable for direct use in industrial applications due to unsound attributes [7]. Physically and chemically modified starch is generally used as a food additive (thickeners, bulking agents, stabilizer, gelling agent, etc.).
Pregelatinization (PG), annealing (ANN), and heatmoisture treatment (HMT) are the main physical modifications which could alter the molecular arrangement in the starch granule [8]. Annealing and heat-moisture treatment do not rupture the granule while [8] acid-thinned modification and lintnerization which refer to the acid-based dextrinization also does not destroy the granular structure $[9,10]$.

The amylose-lipid complex formation is a very important feature which could occur during the hydrothermal modifications (PG, ANN, and HMT) [11-13]. This complex formation is beneficial to food systems which could affect many functional properties of starch such as swelling, solubilization, and thickening power [14].

The acid modification is widely used not only in the food industry but also in paper and textile industries to 
produce thin-boiling starches [15]. Dextrinization is also a very common modification method which is achieved by either thermal or acid catalyzation of starch. In the chemical dextrinization with diluted hydrochloric acid $(\mathrm{HCl})$ referred to as linearization, the modification level of the starch could differ depending on the temperature and duration of the treatment applied [16].

However BeMiller et al. [17] reported that acid molecules preferentially attack the branched molecule while many researchers postulated the opposite idea to above, as acid preferentially buffers the amorphous region [18-20]. Moreover, Biliaderis et al. [21] reported that this hydrolysis accommodates the reorientation of the fragments of the chain to the fore crystalline structure.

There are many analytical methods to identify the changes of modified starch comparable with native starch, such as structuring order within the starch granule by X-ray diffraction (XRD), thermal properties by differential scanning colourimetry (DSC), granular morphology by scanning electron microscope (SEM), swelling power, and viscosity.

It is reported that $\mathrm{X}$-ray diffraction type is a fingerprint of crystal anatomy in the starch granule. Based on the peaks which are formed on the X-ray diffraction graph which is designed based on the crystal structure, starch can be divided into thick main types as A, B, and C. According to the studies of a number of researchers broad classification made as type $A$ of starch mainly represents cereal starches while type B starch is usually reported from tubers. $\mathrm{C}$ pattern which is a mixture of both $\mathrm{A}$ and $\mathrm{B}$ types are available in pea starch and different bean starches [22-24].

Gelatinization is a series of events which are very critical in the product development not only in the food industry but also where applicable [25]. To identify the gelatinization properties differential scanning colourimetry (DSC) can be used as it is an energy absorbing process [26]. Swelling power of flour is a simple study which represents a number of functional characteristics such as gelatinization, swelling volume, thickening capacity, and pasting ability of starch, to predict the suitability of various industrial applications [27]. However, standing few well-known starch sources could not fulfill the high demand for industrial purposes [28]. Therefore, Kithul (Caryota urens) which is one of the significant socioeconomic crops indigenous to India, Sri Lanka, and Malaysia [29] has been detected as a distinct commercially viable starch source.

Kithul flour extracts from the trunk of the palm are another basic example except Sago (Metroxylon sagu Rottb.) for flour derived from the pith. Although this flour is still not used for industrial applications. There is an emerging requirement to discover novel flour source that could fulfill industrial applications and strengthen the rural economy by introducing another expansion of Kithul industry in Sri Lanka. The aim of the current study is to investigate the effects of five different modification methods which represent both physical and chemical modifications versus native flour on physicochemical properties to find out the suitability as a new modified flour source for industrial use. This will help to empower the Kithul flour production in Sri Lanka which directly influences home economy of number of houses in rural areas.

\section{Materials and Methods}

2.1. Flour Sample Collection and Modification. Freshly prepared controlled Kithul flour (RW) samples (under Section 2.1.1) were used for the modifications given in Sections 2.1.1-2.1.3 and all samples were sifted through a $355 \mu \mathrm{m}$ sieve before further analysis.

2.1.1. Preparation of Control Samples. Three Kithul palms from the same area (Kandy, Sri Lanka) were fallen down and split. Pieces of pith were removed (Heartwood pulp) and powdered thoroughly in a mortar. Then, a pot filled with water and a clean cloth is tied to its mouth, after the crushed pith is mixed with water and allowed to strain through the cloth to the pot. The flour settled at the bottom of the pot and the water is skimmed off. Finally, the flour was put in the sun to dry.

2.1.2. Pregelatinization Modifications of Kithul Flour on Quality of Yoghurt. Pregelatinized modification-I (PG-I) was done with a slight modification of method described by Knight [30, 31]. A 1:1 flour solution (100 g flour for $100 \mathrm{~mL}$ deionized water) was incubated at $70^{\circ} \mathrm{C}$ (PG-I) and $75^{\circ} \mathrm{C}$ (PGII) for 5 minutes. Gelatinized flour was dried in a hot air dryer at $40^{\circ} \mathrm{C}$ till moisture level dropped from $10 \%$ to $15 \%$ [30, 31]. Raw Kithul flour was used as the control.

2.1.3. Acidic Modification (AC). The method proposed by Caglarirmak and Cakmakli $[31,32]$ was used for the process. $50 \mathrm{~mL}$ of $0.1 \mathrm{M} \mathrm{HCl}$ solution was added to a mixture of $100 \mathrm{~g}$ of flour and $50 \mathrm{~mL}$ of deionized water and mixed for 30 minutes. Then $\mathrm{pH}$ was adjusted to 7 with $1 \mathrm{M} \mathrm{NaOH}$. Neutralized flour was dried at room temperature $\left(30^{\circ} \mathrm{C}\right)$ following washing and filtered through watchman (No. 1) filter paper. Final $\mathrm{pH}$ of the flour must be 7 .

2.1.4. Dextrinized Modification (DX). The method proposed by Caglarirmak and Cakmakli $[31,32]$ was used with slight modifications. Weight of $75 \mathrm{~g}$ of flour mixed thoroughly with $60 \mathrm{~mL}$ of $0.1 \mathrm{M} \mathrm{HCl}$. Then mixture was dried at $50^{\circ} \mathrm{C}$ for 24 hours (until moisture level dropped to $5 \%$ ). The dried flour again dissolved in $75 \mathrm{~mL}$ deionized water and the $\mathrm{pH}$ was adjusted to 7 by using $1 \mathrm{M} \mathrm{NaOH}$. Then flour was dried in hot air dryer at $40^{\circ} \mathrm{C}$ till moisture level dropped to $10 \%$ to $15 \%$.

\subsection{Analysis of the Flour Properties}

2.2.1. Swelling Power and Solubility. The solubility and swelling power were assayed according to the method described by Leach et al. [33] with slight modifications. Starch $(0.25 \mathrm{~g})$ was heated with $10 \mathrm{~mL}$ of water at $78^{\circ} \mathrm{C}$ for $30 \mathrm{~min}$ with continuous stirring. It was cooled to room temperature and centrifuged at $3000 \mathrm{rpm}$ for $15 \mathrm{~min}$. The supernatant was carefully removed and starch sediment was weighed. The supernatant was taken into a preweighed Petri dish and 
TABLE 1: Granular size, swelling power, and solubility results of modified and native Kithul flour samples.

\begin{tabular}{lcccc}
\hline Sample name & Granular length $(\mu \mathrm{m})$ & Granular width $(\mu \mathrm{m})$ & Swelling power $(\%)$ & Solubility $(\%)$ \\
\hline RW & $45.52 \pm 13.22^{\mathrm{a}}$ & $34.10 \pm 9.88^{\mathrm{a}}$ & $12.63 \pm 0.43^{\mathrm{c}}$ & $4.88 \pm 0.59^{\mathrm{ab}}$ \\
PG-I & $37.22 \pm 10.34^{\mathrm{a}}$ & $27.61 \pm 8.08^{\mathrm{a}}$ & $12.34 \pm 0.39^{\mathrm{c}}$ & $4.47 \pm 0.85^{\mathrm{b}}$ \\
PG-II & $33.27 \pm 12.47^{\mathrm{a}}$ & $24.17 \pm 8.48^{\mathrm{a}}$ & $13.80 \pm 0.26^{\mathrm{a}}$ & $5.31 \pm 0.36^{\mathrm{a}}$ \\
AC & $38.32 \pm 17.82^{\mathrm{a}}$ & $26.18 \pm 10.74^{\mathrm{a}}$ & $13.18 \pm 0.09^{\mathrm{b}}$ & $4.47 \pm 0.37^{\mathrm{b}}$ \\
DX & $42.39 \pm 18.90^{\mathrm{a}}$ & $26.93 \pm 10.70^{\mathrm{a}}$ & $13.92 \pm 0.33^{\mathrm{a}}$ & $4.29 \pm 0.40^{\mathrm{b}}$ \\
\hline
\end{tabular}

All data are the average of three repetitions \pm standard deviation. The values in a column followed by the same letter are not statistically different at a significant level of $5 \%$.

evaporated for $2 \mathrm{~h}$ at $130^{\circ} \mathrm{C}$ and then weighed. The residue obtained after drying of supernatant represented the amount of starch solubilized in water. The result was expressed as

$$
\text { Solubility } \%=\frac{W_{\mathrm{ss}} \times 100}{W_{\mathrm{s}}} .
$$

Here, $W_{\text {ss }}$ is the weight of soluble starch $(\mathrm{g})$ and $W_{\mathrm{s}}$ is the weight of the sample (g):

$$
\text { Swelling power } \%=\frac{W_{\mathrm{sp}} \times 100}{W_{\mathrm{s}} \times(100-\text { Solubility\% })} .
$$

Here, $W_{\text {sp }}$ is the weight of sediment paste $(\mathrm{g})$ and $W_{\mathrm{s}}$ is the weight of the sample (g).

2.2.2. Determination of Granular Size. Size of both modified and native starch granules was observed according to the method described by Jayakody et al. [34] with slight modifications. Starch solution was prepared by mixing with $1: 1(\mathrm{w} / \mathrm{v})$ mixture of distilled water to glycerine $(1: 1, \mathrm{v} / \mathrm{v})$. The starch solution was stained with a $0.05 \%$ iodine solution $(0.05 \mathrm{~g}$ of iodine was dissolved in $100 \mathrm{~mL}$ of $1 \% \mathrm{KI}$ solution) and a thin smear was prepared on a glass slide with a cover slip. Microscopic measurement of Kithul starch granules was done using light microscope (HITACHI SU 6600, Japan) under the magnification power of 400x with Magnus live USB 2.0 viewer and UTHSCSA Image tool for Windows software (developed by University of Texas, 1995-2002). The size of the granules from each starch sample obtained from four different modifications and native form were measured.

\subsubsection{Morphological Characteristics by Scanning Electron} Microscope (SEM). The observation was carried out by following the method used by Senanayake et al. $[35,36]$. Morphology of native and PG-II Kithul flour was studied by using scanning electron microscope (Hitachi SU6600 Analytical Variable Pressure FE-SEM). Starch samples were completely dried overnight $\left(50^{\circ} \mathrm{C}\right)$ and then suspended in ethanol to obtain $1 \%$ suspension. One drop of the starchethanol suspension was applied on an aluminum stub and stub was placed in a dryer for $2 \mathrm{hrs}$. After drying, stubs were coated with gold palladium $(60: 40)$, placed in microscope with an accelerating potential of $15 \mathrm{kV}$, and examined under different magnifications.

2.2.4. X-Ray Diffraction. The X-ray diffraction patterns were recorded with a Bruker D8 Focus Diffractometer (Germany) with EVA data analysis software, under the following conditions: $\mathrm{Cu}-\mathrm{K} \alpha$ radiation $(1.54 \AA)$, a voltage of $40 \mathrm{kV}$, a current of $40 \mathrm{~mA}, 2 \theta$ range from $5^{\circ}$ to $80^{\circ}$, and step size of 0.02 . These studies were done by Analytical Services Division of Sri Lanka Institute of Nanotechnology (Pvt.) Ltd.

2.2.5. Viscosity of Starch by Brookfield Viscometer. A digital Brookfield Viscometer (Model DV-E, M/98-350-CO201) was used to determine the viscosity of all flour treatments by following method of Sopade and Kassam [37]. The starch solution (10\%) was prepared by mixing the Kithul flour of four different modifications (PG-I, PG-II, AC, and DX) and native form (RW) with distilled water. Appropriate spindles (below 10 Cp Spindle No. 2, 11 to 1000 Cp Spindle No. 3, 1001 to 2500 Cp Spindle No. 4, 2501 to 3500 Cp Spindle No. 5, 3501 to 10000 Cp Spindle No. 6, above 10001 Cp Spindle No. 7) were used according to the increment of the viscosity. Samples were continuously heated in a water bath and during heating $\left(62^{\circ} \mathrm{C}\right.$ to $\left.90^{\circ} \mathrm{C}\right)$ and solutions were stirred continuously by a magnetic stirrer. The reading of viscosity in Centipoise was noted at 3 minutes' interval during rotation at $50 \mathrm{rpm}$.

2.3. Statistical Analysis. Results were analyzed using one-way analysis of variance (ANOVA) at 0.05 probability level with MINITAB software package (version 17 for Windows).

\section{Results and Discussion}

According to the proximate composition of the Kithul flour it contains $1.1 \%$ crude fiber, $0.8 \%$ ash, $0.35 \%$ total fat content, $1.0 \%$ crude protein, and $9.3 \%$ moisture content. Carbohydrate content of the Kithul flour is around 87.5\% [38]. Hence it was assumed that if Kithul flour was not to refine as starch, it was not to influence considerably starch properties due to Kithul flour containing carbohydrate as its major component (around 88\%).

Increment of swelling power is showed (Table 1) by all treatments (PG-II, DX, and AC) except PG-I and native Kithul flour. High swelling power of PG-II which has been treated with excess water at high temperature (which was very near to gelatinization peak temperature) may be due to changes in amylose which was complexed with lipid within the granule that is in helical form. It may change its physical forms as partial solubility by the treatment and cause more amorphous which readily leads to combination with moisture to increase the swelling $[35,36]$. However Hoover 
et al. [2] have reported some decrement of swelling with varying level of heat-moisture treatment. It is very clear with results of PG-I treatment (Table 1), though there was not any significant difference between the swelling power of RW and PG-I treatments (12.63 and 12.34 resp.). PG-I has lower swelling power than PG-II (13.80). Although the formation of amylase-lipid complexes during the pregelatinization inhibits the swelling power, the high proportion of long chains (DP > 35 unit chain) influenced increased swelling [39].

Acid-thinned and treated flour (AC) also indicated significantly higher swelling power (13.18) than native flour (12.63), but not much higher than DX (13.92). Similar observation was obtained by Gunaratne [40] for acid-thinned maize and wheat starch from $0.1 \mathrm{M} \mathrm{HCl}$ treatment. According to the postulation of Rohwer and Klem [15] increased shorter chain fraction and decrease of branches may lead to increase of swelling power. DX flour treatment which refers to the lintnerization, modified by diluted $\mathrm{HCl}$, leads to disruption of hydrogen bonding between adjoining polymers of starch which cause structural weakness of the granule. Hence, it is more likely to attach with water molecules which increases the swelling power [41]. This argument is applicable for chemically dextrinized flour treatment which also used $0.1 \mathrm{M}$ $\mathrm{HCl}$.

However the effect of pregelatinization (PG-II) was more pronounced than other chemical treatments. Higher swelling power means lowering of associative force between the granules and hence Kithul flour appears to undergo some reduction in associated force due to modifications except PGI [3].

This study indicates difference in trends of changes in solubility (Table 1). The higher solubility is shown by PG-II (5.31) which is significantly higher than all among treatments due to degradation of flour at higher temperature treatment. These results are comparable with Senanayake et al. [35, 36]. The high solubility of pregelatinization flour treatment may be attributed to the loss of granular structure and release of amylose fraction of the granule [42] which is likely to be solubilized. As the Lawal [43] this trend caused by weaker inter- and intramolecular hydrogen bond after heat-moisture treatments.

The solubility of the acid-thinned flour treatment was 4.47 (Table 1) and it showed a decrement than solubility of native Kithul flour (RW = 4.88). Iheagwara [44] has reported similar results for acid modified sweet potato starch, while Balasubramanian et al. [45] reported the consistent results with this for pearl millet. Many researchers reported increment of solubility after acid modification of Sago [46], Sorghum [47], and cereal starch [41]. Acid treatment has structurally strong granules which resist the leach out [45] compared with native starch granule which refers to the lesser hydrophilicity corresponding to minimized solubility [44].

DX flour treatment which refers to the lintnerization also follows the same behavior. Reduction of solubility after dextrinization is not a common observation according to the partial depolymerization which occurs in the amorphous region [48-50]. However lintnerization describes increasing crystallinity by the remaining crystalline region without undertaking acid hydrolysis [50]. Moreover PalmaRodriguez et al. postulated that acid hydrolysis decreased the chain length with an increased number of short chains [49]. During the recombination which is the second step of dextrinization process these short chains combine in a branched manner [51].

Normally it is reported that amylose content of starch is proportional to the granule size, due to amylose which is amorphous in the starch granules. Larger amylose content of the granule is likely to result in a lesser percentage of crystalline [52].

According to the granule morphological observation AC and DX $(38.32 \mu \mathrm{m}$ and $42.39 \mu \mathrm{m}$, resp.) flour treatments do not show significant differences $(P<0.05)$ with native Kithul flour $(45.52 \mu \mathrm{m})$. The width of the granule behaves in the same pattern (Table 1).

Similar results have been reported by Winarti et al. [50] as lintnerization has no effect on the starch granular morphology while Shildneck and Sumith [53] explained that the physical form of the acid modified starch remains the same. Moreover, many researchers reported comparative findings as their modifications are not based significantly on granular morphology [54].

PG-I and PG-II granular sizes (Figure 1) not significantly $(P<0.05)$ affected by the treatments when compared with the native flour sample. However, by observing the scanning of elector micrographs, the changes could be identified clearly of pregelatinization starch granules with little surface damage. But granular starch has remained because both heat treatments have undergone below the gelatinization peak temperature $\left(T_{p}=78^{\circ} \mathrm{C}\right)$. However few aggregation of starch granules could be observed as random.

Pregelatinizing by drum drier causes damage to the granular structure which goes around $150^{\circ} \mathrm{C}$ heat treatment [55], although this treatment which has been conducted under controlled conditions below the gelatinizing peak $\left(T_{p}\right)$ temperature could protect the granular structure with the same size and shape in Kithul flour.

Variation of viscosity during gelatinization was recorded using Brookfield Viscometer and results elaborated highest viscosity for PG-II treatment while lowest viscosities were reported for DX flour treatment (Figure 2). Pasting properties mainly depend on two factors as the rigidity of the granule [56] and the quantity of amylose leakage [57]. Lower peak viscosity indicates the decrement of swelling capacity.

PG-II treatment causes maintenance of highest viscosities for all temperatures during gelatinization. According to the study of Adebowale et al. [1] heat preferably attacks the amorphous region of granule reducing the molecular mass of analysis and amylopectin molecules which prefer high solubility.

After acid treatment (AC) and lintnerization (DX) it could clearly figure out (Figure 2) rapid reduction of onset, peak, and final viscosity comparably with native Kithul flour. According to the Figure 2, all flour treatments start their increment of viscosity after $72^{\circ} \mathrm{C}$ and lower increment values were observed for AC and DX flour treatments which was acid hydrolyzed. According to the graph (Figure 1) bending points mostly located around $78^{\circ} \mathrm{C}$ for many flour treatments. 


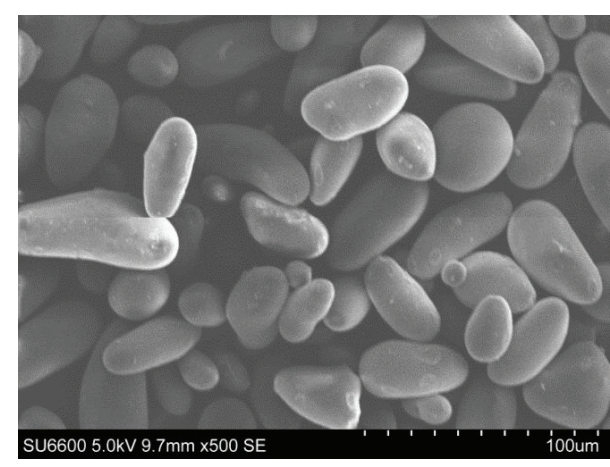

(a)

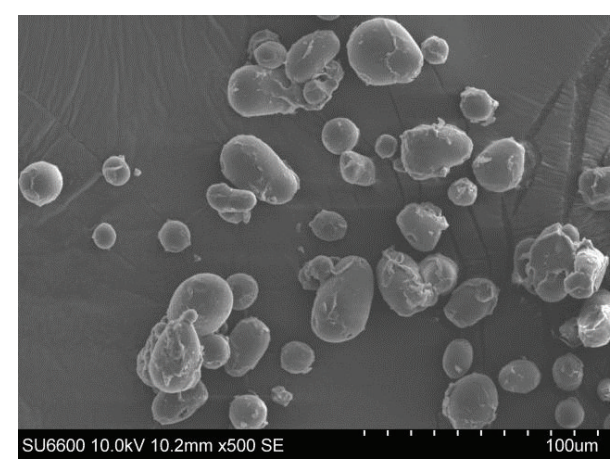

(b)

FIGURE 1: SEM micrograph observations of flour treatments of native (RW (a)) and pregelatinized (PG-II (b)).

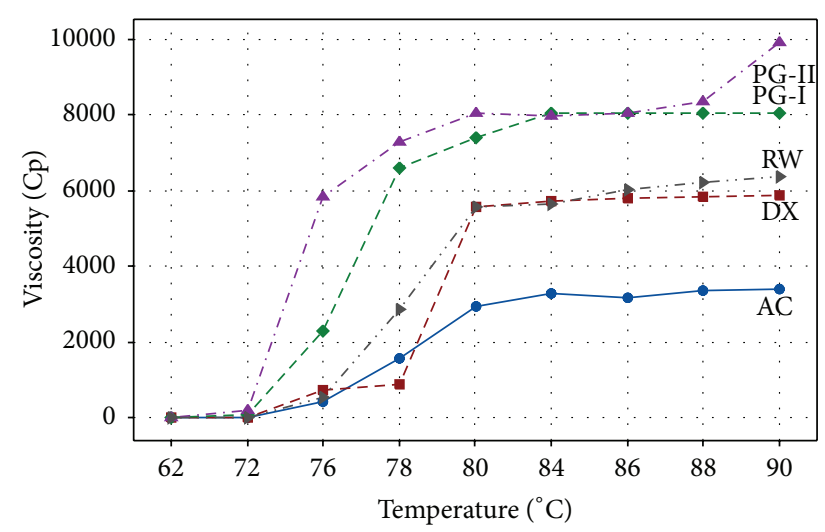

FIGURE 2: Variation of viscosity versus temperature of modified and native Kithul flour.

$90^{\circ} \mathrm{C}$ shows the maximum viscosity of the flour samples during the gelatinization. Acid hydrolyzed AC and DX samples always represented the lowest viscosity which is aligned with the result of Gunaratne [40] as acid treatment where maize flour treatments reported a rapid reduction of peak viscosity. This is mainly attributed to erosion of amorphous region by acid hydrolysis. Formed weak granules are deformable when stirring process which causes to reduce the viscosity.

All the native and modified Kithul flour samples have the same X-ray crystalline pattern (Figures 3 and 4). Major peaks of the graphs have positioned at Bragg's angel $(2 \theta)$ positions near 15 (Peak 1), 17 (Peak 2), 18 (Peak 3), and 23 (Peak 4). These strong diffractions of PG-I, PG-II, DX, AC, and RW flour treatments are evidence for the presence of crystallites which belong to type A $[4,5,24]$. According to the previous studies it has been observed that X-ray diffraction pattern depends on the origin of the starch under environmental growth condition [58]. However these results revealed that used modifications do not charge the crystalline structure in the starch growth which is in agreement with postulation of Waduge et al. [59]. However, there is a possibility of forming amylose-lipid complex PG-I and PG-II due to these undergoing heat treatment. According to Biliaderis [60] formation of complex with ligands (such as fatty acids) is called V-polymorph. XRD diagrams of starch which contain amylose content less than $30 \%$ normally do not represent the presence of V-structure [61-63]. Hence deficit of representing peak for $\mathrm{V}$-type structure on the XRD diagram and analysis does not mean the absence of amylose-lipid complex while it shows the lack of organized three-dimensional structures [60].

\section{Conclusion}

This study revealed that both physical and chemical modifications could influence the physicochemical properties of Kithul (Caryota urens) flour while highest modification is done by physical treatment called PG-II. Swelling power of PG-II was higher (13.80) than swelling power of acidthinned and treated flour $(\mathrm{AC}=13.18)$ and also indicated significantly higher swelling power than native flour (12.63), but not much higher than DX (13.92). The higher solubility is showed by PG-II (5.31) which is significantly higher than all among treatments due to degradation of flour at higher temperature treatment. According to the granule morphological observation AC and DX (38.32 $\mu \mathrm{m}$ and $42.39 \mu \mathrm{m}$, resp.) flour treatments did not show significant differences $(P<0.05)$ with native Kithul flour $(45.52 \mu \mathrm{m})$. The width of the granule behaves in the same pattern. PG-II treatment causes highest viscosities for all temperatures during the gelatinization. All the native and modified Kithul flour sample showed the same $\mathrm{X}$-ray crystalline pattern. These strong diffractions of PGI, PG-II, DX, AC, and RW flour treatments were evidence for the presence of crystallites which belongs to type A. Among four modification methods PG-II presented more favorable properties which make it to be considered as an excellent modification for possible food applications as the highest swelling power and solubility and viscosity remained as chemical free.

\section{Acronyms}

PG- I: Pregelatinization at $70^{\circ} \mathrm{C}$

PG- II: Pregelatinization at $75^{\circ} \mathrm{C}$

AC: Acid modification

DX: Dextrinization 


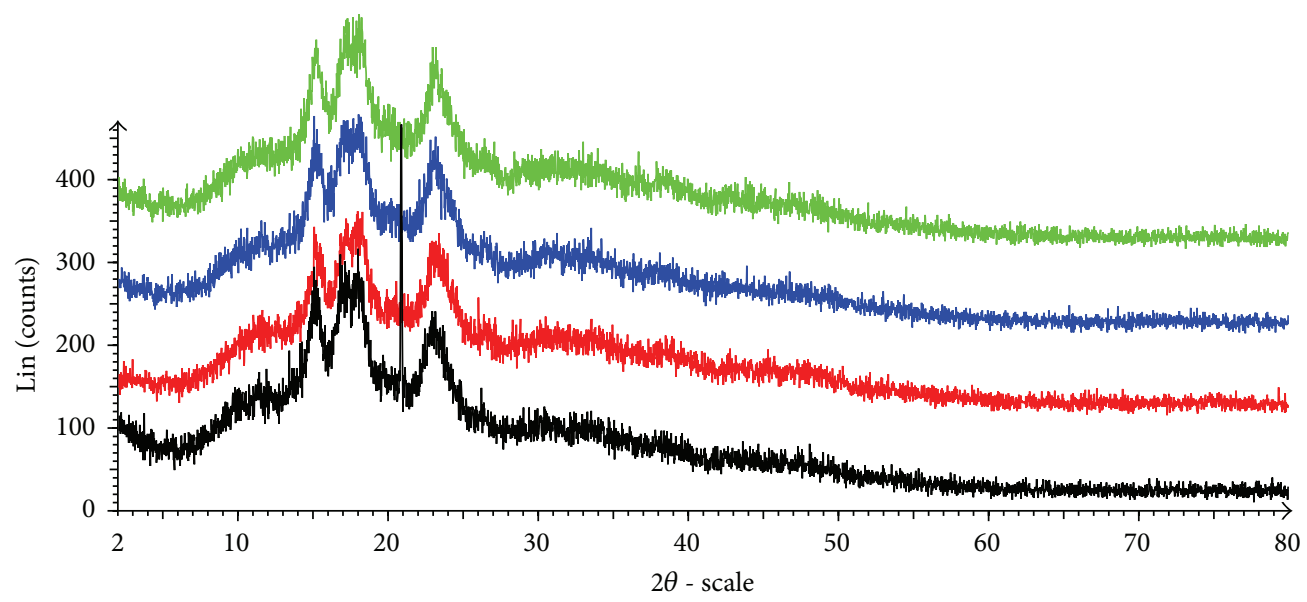

四 AC - file: AC 0606 02.raw - type: 2Th/Th locked - start: $2.000^{\circ}$ - end: $80.000^{\circ}$ - step: $0.020^{\circ}$ - step time: $1 \mathrm{~s}$ temp.: $25^{\circ} \mathrm{C}$ (room) - time started: $11 \mathrm{~s}-2 \theta: 2.000^{\circ}-\theta: 1.000^{\circ}-\chi: 0.00^{\circ}-\phi: 0.00^{\circ}-X: 0.0 \mathrm{~mm}-$ operations: import

四 $Y+20.0 \mathrm{~mm}$ - DX - file: DX 0606 02.raw - type: $2 \mathrm{Th} / \mathrm{Th}$ locked - start: $2.000^{\circ}$ - end: $80.000^{\circ}$ - step: $0.020^{\circ}$ step time: $1 \mathrm{~s}$ - temp.: $25^{\circ} \mathrm{C}(\mathrm{room})$ - time started: $11 \mathrm{~s}-2 \theta: 2.000^{\circ}-\theta: 1.000^{\circ}-\chi: 0.00^{\circ}-\phi: 0.00^{\circ}$ operations: import

四 $Y+40.0 \mathrm{~mm}$ - PG - file: pg 0606 02.raw - type: $2 \mathrm{Th} / \mathrm{Th}$ locked - start: $2.000^{\circ}$ - end: $80.000^{\circ}$ - step: $0.020^{\circ}$ step time: $1 \mathrm{~s}$ - temp.: $25^{\circ} \mathrm{C}$ (room) - time started: $8 \mathrm{~s}-2 \theta: 2.000^{\circ}-\theta: 1.000^{\circ}-\chi: 0.00^{\circ}-\phi: 0.00^{\circ}-$ operations: import

四 $Y+60.0 \mathrm{~mm}$ - RW - file: rw 0606 02.raw - type: $2 \mathrm{Th} / \mathrm{Th}$ locked - start: $2.000^{\circ}$ - end: $80.000^{\circ}$ - step: $0.020^{\circ}$ step time: $1 \mathrm{~s}$ - temp.: $25^{\circ} \mathrm{C}$ (room) - time started: $10 \mathrm{~s}-2 \theta: 2.000^{\circ}-\theta: 1.000^{\circ}-\chi: 0.00^{\circ}-\phi: 0.00^{\circ}$ operations: import

Figure 3: X-ray diffraction pattern of native (RW) and three modified flour treatments (AC, DX, and PG-I). Array from top to bottom as AC, DX, PG-I, and RW.

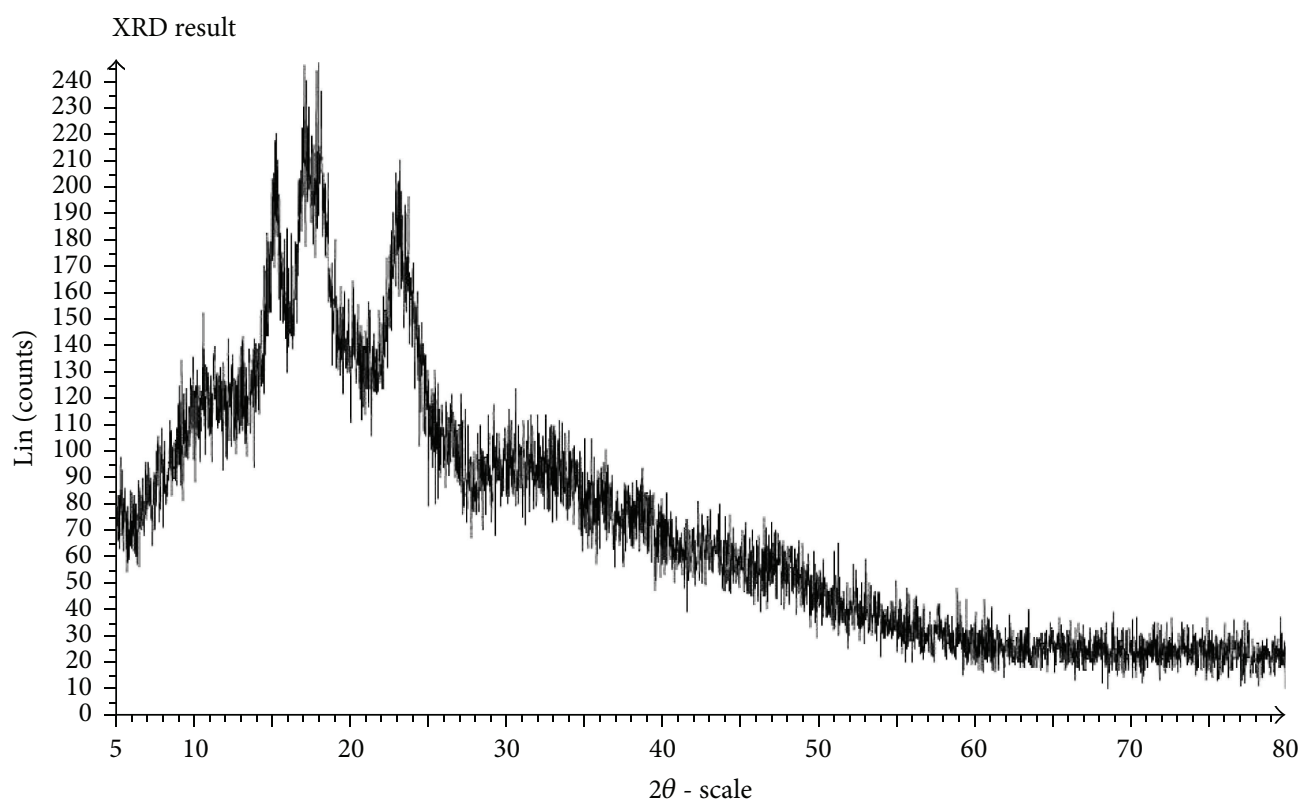

四 PG-II - file: PG-II - 0.6, 0.6, 0.2.raw - type: 2 Th/Th locked - start: $5.000^{\circ}$ - end: $80.000^{\circ}$ - step: $0.020^{\circ}$ step time: $1 \mathrm{~s}$ - temp.: $25^{\circ} \mathrm{C}$ (room) - time started: $3 \mathrm{~s}-2 \theta: 5.000^{\circ}-\theta: 2.500^{\circ}-\chi: 0.00^{\circ}-\phi: 0.00^{\circ}-X: 0.0 \mathrm{~m}$ operations: import

FIGURE 4: X-ray diffraction pattern of PG-II flour treatment. 
XRD: X-ray diffraction

ANN: Annealing

HMT: Heat-moisture treatment

DSC: Differential scanning colourimetry

SEM: Scanning electron microscope

RW: Native Kithul flour

$\mathrm{HCl}$ Hydrochloric acid

$\mathrm{NaOH}$ : Sodium hydroxide

Cp: Centipoise (unit for measure the viscosity).

\section{Competing Interests}

The authors declare that they have no competing interests.

\section{Acknowledgments}

The authors tender their sincere thanks to the University of Sri Jayewardenepura, Sri Lanka, for providing financial assistance for this study (Grant no. ASP/06/RE/SCI/2012/04). Last but not least the authors tender their sincere gratitude to Dr. B. M. K. S. Tilakaratne, Director of Institute of Post-Harvest Technology Research and Development Centre, Anuradhapura, Sri Lanka, and Dr. M. A. P. K. Seneviratne, Department of Export Agriculture, Peradeniya. Special thanks are due to Ms. Filicia Weerawardene, Mrs. Sujatha Ettipola, Mr. Janitha Ambagaspitiya, and Ms. Chilani Wijesinghe for the assistance provided.

\section{References}

[1] K. O. Adebowale, B. I. Olu-Owolabi, O. O. Olayinka, and O. S. Lawal, "Effect of heat moisture treatment and annealing on physicochemical properties of red sorghum starch," African Journal of Biotechnology, vol. 4, no. 9, pp. 928-933, 2005.

[2] R. Hoover, S. C. Rorke, and A. M. Martin, "Isolation and characterization of lima bean (Phaseolus lunatus) starch," Journal of Food Biochemistry, vol. 15, no. 2, pp. 117-136, 1991.

[3] A. Yusuf, H. Ayedun, and G. B. Logunleko, "Functional properties of unmodified and modified Jack bean (Canavalia ensiformis) starches," Nigerian Food Journal, vol. 25, no. 2, 2010.

[4] H. Dutta and C. L. Mahanta, "Effect of hydrothermal treatment varying in time and pressure on the properties of parboiled rices with different amylose content," Food Research International, vol. 49, no. 2, pp. 655-663, 2012.

[5] M. Marimuthu, U. Sundaram, and P. Gurumoorthi, "X-ray diffraction and starch analysis of nano sized seed powder of velvet bean (Mucuna pruriens)," Indo American Journal of Pharmaceutical Research, vol. 3, no. 2, 2013.

[6] Y. Pomaranz, Functional Properties of Food Components, Academic Press, New York, NY, USA, 1991.

[7] D. F. Coral, P. Pineda-Gómez, A. Rosales-Rivera, and M. E. Rodriguez-Garcia, "Determination of the gelatinization temperature of starch presented in maize flours," Journal of Physics: Conference Series, vol. 167, no. 1, Article ID 012057, 2009.

[8] S.-T. Lim, E.-H. Chang, and H.-J. Chung, "Thermal transition characteristics of heat-moisture treated corn and potato starches," Carbohydrate Polymers, vol. 46, no. 2, pp. 107-115, 2001.
[9] Y.-C. Shi and P. A. Seib, "The structure of four waxy starches related to gelatinization and retrogradation," Carbohydrate Research, vol. 227, pp. 131-145, 1992.

[10] O. S. Lawal, K. O. Adebowale, B. M. Ogunsanwo, L. L. Barba, and N. S. Ilo, "Oxidized and acid thinned starch derivatives of hybrid maize: functional characteristics, wide-angle X-ray diffractometry and thermal properties," International Journal of Biological Macromolecules, vol. 35, no. 1-2, pp. 71-79, 2005.

[11] M. Kugimiya, J. W. Donovan, and R. Y. Wong, "Phase transition of amylose-lipid complexes in starches: a calorimetric study," Starke, vol. 32, no. 8, pp. 265-270, 1980.

[12] M. Kugimiya and J. W. Donovan, "Calorimetric determination of the amylose content of starches based on formation and melting of amylose-lysolecithin complex," Journal of Food Science, vol. 46, no. 3, pp. 765-770, 1981.

[13] C. G. Biliaderis, C. M. Page, L. Slade, and R. R. Sirett, "Thermal behavior of amylose-lipid complexes," Carbohydrate Polymers, vol. 5, no. 5, pp. 367-389, 1985.

[14] T. Galliard and P. Bowler, "Morphology and composition of starch," in Starch: Properties and Potential, T. Galliard, Ed., pp. 55-79, John Wiley \& Sons, Chichester, UK, 1987.

[15] R. G. Rohwer and R. E. Klem, "Acid-modified starch: production and uses," in Starch: Chemistry and Technology, R. L. Whistler, J. N. BeMiller, and E. F. Paschall, Eds., chapter 17, pp. 529-541, Academic Press, London, UK, 2nd edition, 1984.

[16] P. Thomasik, Chemical and Functional Properties of Food Sacchirades, CRC Press, Taylor and Francis Group, Boca Raton, Fla, USA, 2003.

[17] J. N. BeMiller, "Acid hydrolysis and lytic reactions of starch," in Starch Chemistry and Technology, R. L. Whistler and E. F. Paschall, Eds., vol. 1, p. 495, Academic Press, New York, NY, USA, 1965.

[18] C. G. Biliaderis, D. R. Grant, and J. R. Vose, "Structural characterization of legume starches. II. Studies on acid-treated starches," Cereal Chemistry, vol. 58, pp. 502-507, 1981.

[19] J. Chun, S. Lim, Y. Takeda, and M. Shoki, "Properties of highcrystalline rice amylodextrins prepared in acid-alcohol media as fat replacers," Cereal Foods World, vol. 42, no. 10, pp. 813-819, 1997.

[20] N. K. Genkina, V. I. Kiseleva, and T. Noda, "Comparative investigation on acid hydrolysis of sweet potato starches with different amylopectin chain-length," Starch, vol. 61, no. 6, pp. 321-325, 2009.

[21] C. G. Biliaderis, T. J. Maurice, and J. R. Vose, "Starch gelatinization phenomenon studies by differential scanning calorimetry," Journal of Food Science, vol. 45, pp. 1169-1674, 1980.

[22] R. Hoover and W. S. Ratnayake, "Starch characteristics of black bean, chick pea, lentil, navy bean and pinto bean cultivars grown in Canada," Food Chemistry, vol. 78, no. 4, pp. 489-498, 2002.

[23] W. S. Ratnayake, R. Hoover, F. Shahidi, C. Perera, and J. Jane, "Composition, molecular structure, and physicochemical properties of starches from four field pea (Pisum sativum L.) cultivars," Food Chemistry, vol. 74, no. 2, pp. 189-202, 2001.

[24] J. Zeng, G. Li, H. Gao, and Z. Ru, "Comparison of A and B starch granules from three wheat varieties," Molecules, vol. 16, no. 12, pp. 10570-10591, 2011.

[25] Z. Ertugay and H. G. Kotancialar, "Relations between physicochemical properties of starch and firmness of crumb," Gida, vol. 13, pp. 115-121, 1998. 
[26] M. M. Karaoğlu, H. G. Kotancilar, and N. Aktaş, "Effect of different modification techniques on the physicochemical and thermoanalytical properties of wheat and corn starch," Journal of Tekirdăg Agricultural Faculty, vol. 3, no. 2, pp. 83-90, 2006.

[27] J. Blazek, Role of amylose in structure-function relationship in starches from Australian wheat varieties [Ph.D. thesis], Faculty of Agriculture, Food and Natural Resources, The University of Sydney, 2008.

[28] A. O. Ashogbon and E. T. Akintayo, "Recent trend in the physical and chemical modification of starches from different botanical sources: a review," Starch/Staerke, vol. 66, no. 1-2, pp. 41-57, 2014.

[29] P. Rajyalakshmi, "Caryota palm sago O A potential get underutilized natural resource for modern starch industry," Naturakl Product Redience, vol. 3, no. 3, pp. 144-149, 2004.

[30] J. W. Knight, The Starch Industry, Pergman Press, Oxford, UK, 1969.

[31] M. M. Karaoğlu, H. G. Kotancilar, and I. Çelik, "Effects of utilization of modified starches on the cake quality," Starch, vol. 53, no. 3-4, pp. 162-169, 2001.

[32] N. Caglarirmak and U. Cakmakli, "Değiş̧ik Modifiye Nişastaların Üretiminde Kimyasal Prensipler," Gida, vol. 18, no. 2, pp. 131-137, 1993.

[33] H. W. Leach, L. D. McCowen, and T. J. Schoch, "Structure of the starch granule. I. Swelling and solubility patterns of various starches," Cereal Chemistry, vol. 36, pp. 534-544, 1959.

[34] S. W. P. Jayakody, Evaluation of physiochemical properties and morphology of starches of Kithul (Caryota urens), Kuru Kithul (Caryota plumose) and their hybrid [M.S. thesis], Department of Food Science \& Technology, University of Peradeniya, 2009.

[35] S. Senanayake, A. Gunaratne, K. K. D. S. Ranaweera, and A. Bamunuarachchi, "Physico-chemical properties of five cultivars of sweet potato (Ipomea batatas Lam (L)) root tubers grown in Sri Lanka," Tropical Agriculture, vol. 90, no. 2, pp. 87-96, 2013.

[36] S. A. Senanayake, K. K. D. S. Ranaweera, A. Gunaratne, and A. Bamunuarachchi, "Effect of heat moisture treatment conditions on swelling power and water soluble index of different cultivars of sweet potato (Ipomea batatas (L). Lam) starch," ISRN Agronomy, vol. 2013, Article ID 502457, 4 pages, 2013.

[37] P. A. Sopade and A. L. Kassam, "Rheological characterization of akamu, a semi-liquid food made from maize, millet and sorghum," Journal of Cereal Science, vol. 15, no. 2, pp. 193-202, 1992.

[38] J. A. A. C. Wijesinghe, I. Wicramasinghe, and K. H. Saranandha, "Deviation of chemical properties of Kithul flour (Caryota urens) obtained from five different growing areas in Sri Lanka," International Journal of Innovative Research in Technology, vol. 2, no. 25, pp. 67-76, 2015.

[39] A. L. Charles, Y. H. Chang, W. C. Ko, K. Sriroth, and T. C. Huang, "Influence of amylopectin structure and amylose content on the gelling properties of five cultivars of cassava starches," Journal of Agricultural and Food Chemistry, vol. 53, no. 7, pp. 2717-2725, 2005.

[40] A. Gunaratne, Physical and chemical modification of some cereal, tuber and root starches and the roles of 221-cyclodextrin as a starch modifyingagent [Ph.D. of Philosophy], The University of Hong Kong, Hong Kong, 2006, http://hdl.handle.net/10722/ 50221 .

[41] L. Jayakody and R. Hoover, "The effect of lintnerization on cereal starch granules," Food Research International, vol. 35, no. 7, pp. 665-680, 2002.
[42] L. A. Stone, K. Lorenz, and F. Collins, "The starch of amaranthus-physico-chemical properties and functional characteristics," Starch, vol. 36, no. 7, pp. 232-237, 1984.

[43] O. S. Lawal, "Starch hydroxyalkylation: physicochemical properties and enzymatic digestibility of native and hydroxypropylated finger millet (Eleusine coracana) starch," Food Hydrocolloids, vol. 23, no. 2, pp. 415-425, 2009.

[44] M. C. Iheagwara, "Isolation, modification and characterization of sweet potato (Ipomoea batatas L (Lam) starch," Journal of Food Process Technology, vol. 4, article 198, 2013.

[45] S. Balasubramanian, R. Sharma, J. Kaur, and N. Bhardwaj, "Characterization of modified pearl millet (Pennisetum typhoides) starch," Journal of Food Science and Technology, vol. 51, no. 2, pp. 294-300, 2014.

[46] M. N. Abdorreza, M. Robal, L. H. Cheng, A. Y. Tajul, and A. A. Karim, "Physicochemical, thermal, and rheological properties of acid-hydrolyzed sago (Metroxylon sagu) starch," LWT-Food Science and Technology, vol. 46, no. 1, pp. 135-141, 2012.

[47] H. Singh, N. S. Sodhi, and N. Singh, "Structure and functional properties of acid thinned sorghum starch," International Journal of Food Properties, vol. 12, no. 4, pp. 713-725, 2009.

[48] O. V. López, N. E. Zaritzky, and M. A. García, "Physicochemical characterization of chemically modified corn starches related to rheological behavior, retrogradation and film forming capacity," Journal of Food Engineering, vol. 100, no. 1, pp. 160-168, 2010.

[49] H. M. Palma-Rodriguez, E. Agama-Acevedo, G. MendezMontealvo, R. A. Gonzalez-Soto, E. J. Vernon-Carter, and L. A. Bello-Pérez, "Effect of acid treatment on the physicochemical and structural characteristics of starches from different botanical sources," Starch, vol. 64, no. 2, pp. 115-125, 2012.

[50] C. Winarti, T. C. Sunarti, D. Mangunwidjaja, and N. Richana, "Preparation of arrowroot starch nanoparticles by butanolcomplex precipitation, and its application as bioactive encapsulation matrix," International Food Research Journal, vol. 21, no. 6, pp. 2207-2213, 2014.

[51] L. Effah-Manu, I. Oduro, and A. Addo, "Effect of dextrinized sweet potatoes on the physicochemical and sensory quality of infra-red dried mango leather," Journal of Food Processing \& Technology, vol. 4, article 230, 2013.

[52] D. D. Pan and J.-L. Jane, "Internal structure of normal maize starch granules revealed by chemical surface gelatinization," Biomacromolecules, vol. 1, no. 1, pp. 126-132, 2000.

[53] P. Shildneck and C. E. Sumith, "Production and uses of acid modified starch," in Starch: Chemistry and Technology, R. L. Whistler and E. F. Paschall, Eds., vol. 2, chapter 9, Academic Press, New York, NY, USA, 1967.

[54] T. M. Ali and A. Hasnain, "Functional and morphological characterization of low-substituted acetylated white sorghum (Sorghum bicolor) starch," International Journal of Polymer Analysis and Characterization, vol. 16, no. 3, pp. 187-198, 2011.

[55] M. Majzoobi, M. Radi, A. Farahnaky, J. Jamalian, T. Tongdang, and G. Mesbahi, "Physicochemical properties of pre-gelatinized wheat starch produced by a twin drum drier," Journal of Agricultural Science and Technology, vol. 13, no. 2, pp. 193-202, 2011.

[56] M. R. Sandhya Rani and K. R. Bhattacharya, "Rheology of riceflour pastes: effect of variety, concentration, and temperature and time of cooking," Journal of Texture Studies, vol. 20, no. 2, pp. 127-137, 1989.

[57] V. J. Morris, “Starch gelation and retrogradation," Trends in Food Science and Technology, vol. 1, pp. 2-6, 1990. 
[58] J. Huang, H. A. Schols, J. J. G. van Soest, Z. Jin, E. Sulmann, and A. G. J. Voragen, "Physicochemical properties and amylopectin chain profiles of cowpea, chickpea and yellow pea starches," Food Chemistry, vol. 101, no. 4, pp. 1338-1345, 2007.

[59] R. N. Waduge, R. Hoover, T. Vasanthan, J. Gao, and J. Li, “Effect of annealing on the structure and physicochemical properties of barley starches of varying amylose content," Food Research International, vol. 39, no. 1, pp. 59-77, 2006.

[60] C. G. Biliaderis, "Structures and phase transition of starch polymers," in Polysaccharide Association Structures in Food, R. H. Walter, Ed., pp. 57-168, Marcel Dekker, New York, NY, USA, 1998.

[61] H. F. Zobel, "Starch crystal transformations and their industrial importance," Starch, vol. 40, no. 1, pp. 1-7, 1988.

[62] C. Gernat, S. Radosta, H. Anger, and G. Damaschun, "Crystalline parts of three different conformations detected in native and enzymatically degraded starches," Starch, vol. 45, no. 9, pp. 309-314, 1993.

[63] H. F. Zobel, "Starch granule structure," in Developments in Carbohydrate Chemistry, R. J. Alexander and H. F. Zobel, Eds., pp. 1-36, American Association of Cereal Chemists, St. Paul, Minn, USA, 1992. 

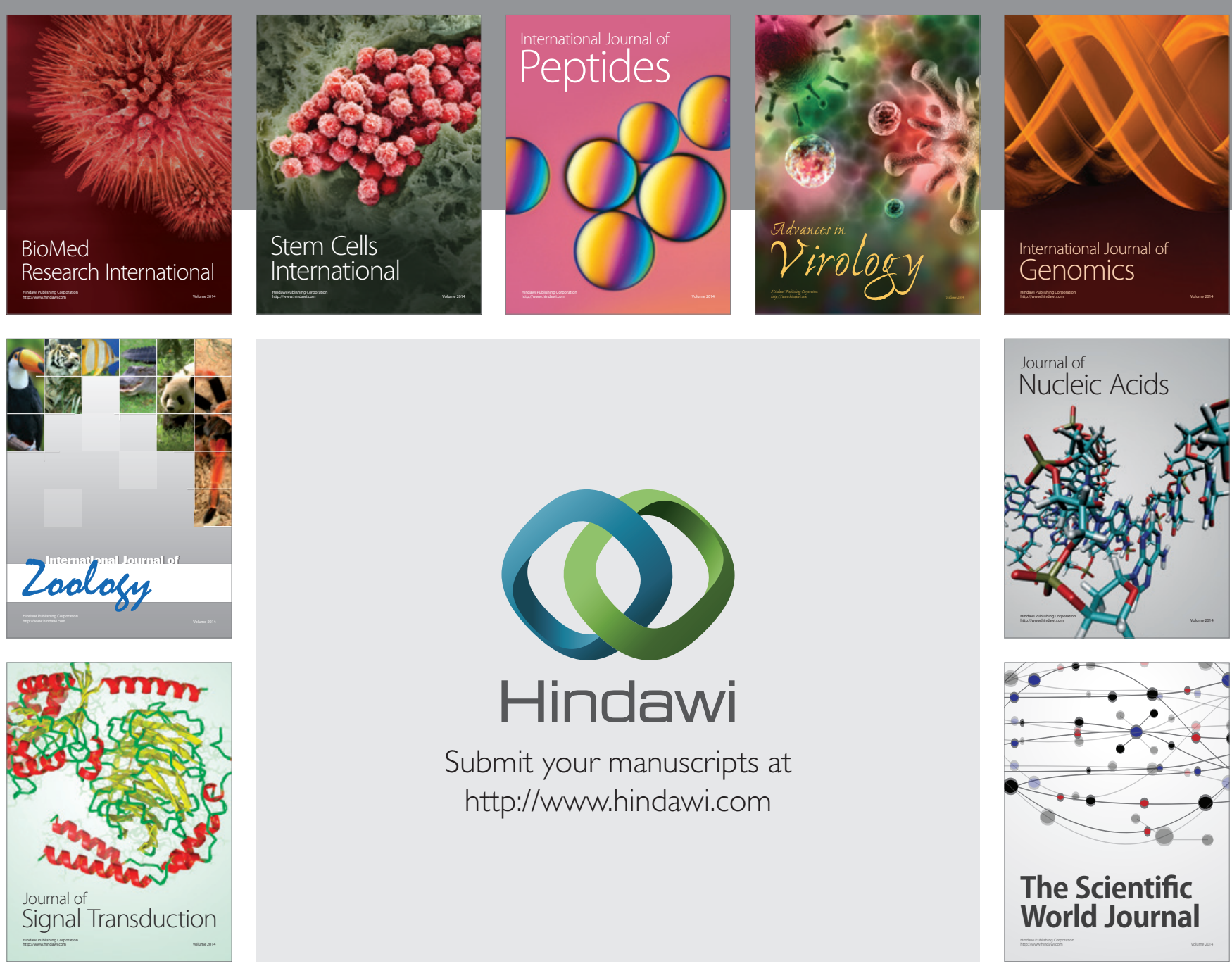

Submit your manuscripts at

http://www.hindawi.com
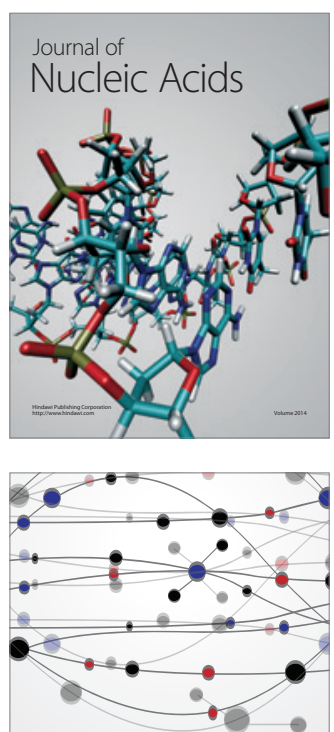

The Scientific World Journal
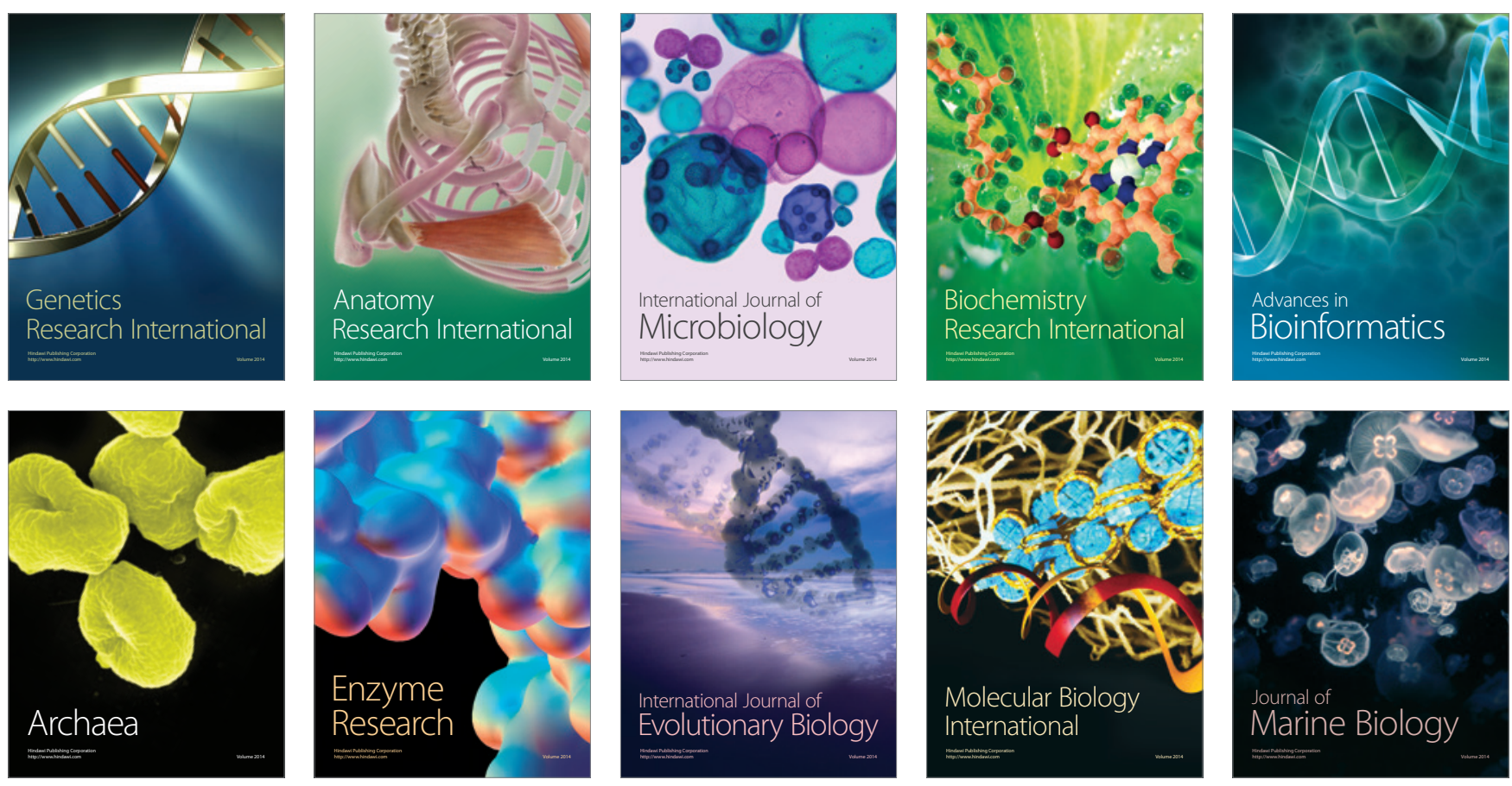